\title{
FORMAÇÃO CONTINUADA COLABORATIVA: UMA EXPERIÊNCIA DE PESQUISA
}

\author{
Andréia Cristina de Souqa* \\ Terezinha da Conceição Costa-Hübes*
}

RESUMO: O objetivo deste artigo é apresentar os resultados parciais de uma pesquisa-ação-críticocolaborativa (PACC) (PIMENTA, 2005), desenvolvida no âmbito de formação continuada de professores dos anos iniciais do ensino fundamental, com o intuito de investigar se as ações colaborativas propostas provocariam alterações nas concepções de linguagem dos professores participantes. Alinhada às preocupações da Linguística Aplicada, desenvolvemos uma pesquisa qualitativa interpretativista (BORTONI-RICARDO, 2008), seguindo os pressupostos da PACC, em uma adaptação da proposta de Magalhães (2004). A partir da compreensão de que as concepções de linguagem afetam os encaminhamentos metodológicos do trabalho com a linguagem (GERALDI, 2011 [1984]), a formação ocorreu no segundo semestre de 2019, e contou, inicialmente, com a participação de 74 professores, em seis encontros distribuídos ao longo do semestre, totalizando 24 horas. A partir da análise de cartazes produzidos ao inicial e ao final da formação, verificamos que houve uma mudança significativa das concepções apresentadas pelos participantes.

PALAVRAS-CHAVE: Ações colaborativas; Formação de professores; Pesquisa-ação-crítico-colaborativa.

\section{Introdução}

Uma das preocupações centrais da Linguística Aplicada (LA) no Brasil, na modernidade recente, consiste em focalizar o tratamento dado às práticas de uso da linguagem em contextos escolares - da sala de aula, aos sujeitos envolvidos e aos materiais didáticos -, em um mundo que passa por mudanças cada vez mais prementes, em seus conflitos e negociações, visando buscar alternativas para "alterar o presente e reinventar o mundo social" (MOITA LOPES, 2013, p. 20).

No livro organizado por Moita Lopes (2013) verificamos que problematizar as práticas de linguagem nesse contexto pressupõe, também, problematizar a formação inicial e

\footnotetext{
* Professora do Curso de Letras da Universidade Federal da Fronteira Sul (UFFS), Campus Realeza. Doutora em Letras pela Universidade Estadual do Oeste do Paraná (Unioeste).

${ }^{*}$ Professora Associada da Universidade Estadual do Oeste do Paraná (Unioeste). Doutora em Estudos da Linguagem pela Universidade Estadual de Londrina (Uel).
} 
continuada de professores e a organização disciplinar da escola no passado (KLEIMAN, 2013; LEFFA, 2013; BOHN, 2013; MILLER, 2013; CAVALCANTI, 2013). É o que já mostrou Soares (2002), ao percorrer o caminho da Língua Portuguesa (doravante LP) enquanto disciplina na escola, tecendo reflexões sobre como esse percurso refletiu na identidade e na formação dos professores. Segundo a autora, apenas a partir dos anos 1930 do século XX é que passaram a existir cursos de formação de professor. Já a partir dos anos 1950, a democratização do ensino e o consequente aumento do número de alunos exigiram também o aumento do número de professores em tempo recorde. Esse aumento, no entanto, mudou também o perfil de alunos e professores. Com isso, os manuais didáticos passaram a servir como suporte irrestrito ao professor. Segundo a autora, isso se dá em decorrência da intensificação, à essa época, do "processo de depreciação da função docente", o que colaborou com a precarização das condições de trabalho que persiste até os dias atuais. $\mathrm{O}$ resultado, segundo Soares, foi "obriga[r] os professores a buscar estratégias de facilitação de sua atividade docente - uma delas é transferir ao livro didático a tarefa de preparar aulas e exercícios" (SOARES, 2002, p. 167), dificultando, então, o caráter crítico e reflexivo necessário para o ensino.

Ainda que essa crise da identidade docente em nossa sociedade - também abordada por Guedes (2006) -, ao que parece, esteja longe de ser superada, movimentos que busquem investir na formação dos professores continuam imperativos. Para esse caminho, já apontava Geraldi, desde os anos 1980, ao questionar os resultados das avaliações de ensino de LP, no Brasil, e relacioná-los à formação docente. Geraldi (2011[1984]) nos lembra que é imprescindível reconhecer o papel desse profissional nos resultados, sem, no entanto, responsabilizá-lo por todas as mazelas do ensino. Enfatiza, então, a necessidade de investir na formação continuada, considerando o contexto contraditório de atuação no ensino para "buscar um espaço [...] em que se delineie um fazer agora, na escola que temos, alguma coisa que nos aproxime da escola que queremos, mas que depende de determinantes externos aos limites da ação da e na própria escola” (GERALDI, 2011[1984], p. 40). A partir dessa consideração, o autor sugere encaminhamentos que, ainda hoje, chamamos de "novas propostas para o ensino de LP”, focalizando práticas em vez de conteúdos, alunos como 
sujeitos de seu conhecimento, texto como unidade e objeto de ensino e a interação entre esses sujeitos

Levar em consideração a proposta defendida por Geraldi - e por tantos outros significa assumir uma mudança de posicionamento: o professor deixa de ser simples aplicador de conteúdos previamente apresentados no livro didático, conforme problematiza Soares (2002), e adota uma postura crítica e reflexiva sobre a própria prática e sobre o contexto de ensino em que atua. Entretanto, nem sempre nós, professores de LP, saímos do curso de graduação com essas capacidades desenvolvidas e com uma base epistemológica, teórica e metodológica consistente que nos permita desenvolver um trabalho diferenciado em relação à formação a que, na maioria das vezes, fomos expostos, durante a educação básica. Ainda que a graduação seja essencial na formação inicial do docente, com a sua atuação profissional poderão surgir outros desafios sobre os quais precisará se debruçar. Por isso, urge a necessidade de que tenha acesso a processos de formação continuada que lhe permitam (re)visitar conhecimentos e procedimentos teórico-metodológicos adquiridos anteriormente.

Ao considerarmos a relevância dessa necessidade, visamos a apresentar, por meio

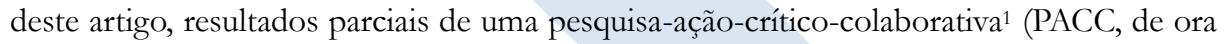
em diante) (PIMENTA, 2005), desenvolvida no âmbito de formação continuada de professores dos anos iniciais do ensino fundamental, no sudoeste do Paraná. O objetivo da pesquisa foi refletir sobre as contribuições de ações colaborativas na compreensão da linguagem como forma de interação em encaminhamentos didático-pedagógicos nos anos iniciais do Ensino Fundamental.

Alinhadas às preocupações da LA, desenvolvemos uma pesquisa qualitativa interpretativista (BORTONI-RICARDO, 2008). A partir da compreensão de que nossas concepções de linguagem afetam diretamente os encaminhamentos metodológicos do trabalho

\footnotetext{
${ }^{1}$ Essa pesquisa faz parte do estágio de pós-doutoramento em andamento no Programa de Pós-Graduação em Letras da Universidade Estadual do Oeste do Paraná, no período de agosto/2019 a julho/2020, sob a supervisão da Profa. Dra. Terezinha da Conceição Costa-Hübes.
} 
com a linguagem em sala de aula (GERALDI, 2011 [1984]), buscamos investigar se as ações colaborativas propostas provocaram alterações nas concepções de linguagem dos professores participantes, para, por consequência, possibilitar também alterações nos encaminhamentos metodológicos das aulas de LP. Para isso, propusemos, em parceria com as secretarias municipais de educação de dois municípios do sudoeste do Paraná, um trabalho de formação continuada colaborativa com professores dos anos iniciais do Ensino Fundamental, focalizado, conforme a necessidade apresentada pela comunidade escolar, na produção e reescrita de textos. A formação ocorreu no segundo semestre de 2019, e contou, inicialmente, com a participação de 74 professores, em seis encontros distribuídos ao longo do semestre, totalizando 24 horas de estudos.

A motivação para esta pesquisa surgiu com a preocupação dos munícipios em adequar seus currículos e propostas pedagógicas a partir da Base Nacional Comum Curricular (BNCC - BRASIL, 2017). Secretarias da educação, coordenações pedagógicas e professores não se sentiam aptos a trabalhar com a linguagem em uma concepção interacionista, apesar de ser o percurso já proposto pelos Parâmetros Curriculares Nacionais (PCN BRASIL, 1997). Assim, mais do que estudos teóricos, a demanda dos professores era por compreender as possibilidades metodológicas para o trabalho com LP em sala de aula. Se consideramos que as raízes epistemológicas para essa compreensão da linguagem têm origem nas reflexões do Círculo de Bakhtin, orientadas para o ensino de LP por meio das reflexões teórico-metodológicas realizadas por Geraldi (2011[1984]), mostrou-se necessário ir além do caráter prescritivo, em busca de uma receita "pronta" para as aulas de LP (MILLER, 2013). Uma das alternativas que visualizamos, então, foi o caminho da colaboração. Desse modo, visando a atender este número de professores, com a limitação de tempo de formação que tinham disponível2 ${ }^{2}$ adaptamos a proposta de Magalhães (2004) para o trabalho colaborativo em formação continuada.

\footnotetext{
${ }^{2}$ Cada município dispõe, em seu planejamento anual, de uma carga horária para formação continuada, quando o professor é dispensado de suas atividades em sala para participar de processos formativos que, geralmente, são ofertados pelos próprios municípios. Todavia, todo o processo de formação que vivenciamos com esses docentes ocorreram em horário extracurricular, no final do turno vespertino de trabalho.
} 
Assim, a presente pesquisa justifica-se justamente por buscar possibilidades de formação continuada, visando à transformação social, somando-se às demais pesquisas na área de formação de professores sob a perspectiva da LA, no viés colaborativo, partindo da demanda dos docentes, de modo a propor possibilidades efetivas para o trabalho com a linguagem em sala de aula. Embora outras pesquisas já tenham se debruçado sobre esse tema (GEDOZ, 2011; TURKIEWICZ, 2016; ROSSI, 2019, dentre outras), defendemos a relevância desta investigação por ter se voltado para uma necessidade real apontada pelos participantes e por ter buscado colaborar, por meio de reflexões contínuas e discussões referentes aos encaminhamentos teórico-metodológicos apresentados por documentos oficiais de ensino (mais especificamente a BNCC - BRASIL, 2017) no trabalho com a linguagem em práticas de produção e reescrita textual.

Com o propósito de socializar essa experiência investigativa, dividimos o artigo em duas partes. Na primeira, refletimos sobre os pressupostos teóricos que subsidiaram o processo de formação continuada, dentro da PACC. Na segunda, apresentaremos os procedimentos adotados na formação continuada, destacando alguns dos resultados alcançados.

\section{Formação continuada colaborativa: compreensões subjacentes}

A publicação da BNCC (BRASIL, 2017), surpreendeu, de certa forma, os Estados e Municípios, pelo seu caráter normativo, ou, conforme Bonini e Costa-Hübes (2019), pela sua proposta de unificação dos conteúdos mínimos "que devem estar presentes em todas as escolas do país, pela primeira vez unificadas como sistema, via pacto federativo" (BONINI; COSTA-HÜBES, 2019, p. 26), incidindo sobre a composição dos currículos estaduais e municipais. Embora o documento tenha sido instituído de forma arbitrária, desconsiderando a autonomia dos estados, munícipios e instituições escolares, forçando a adesão a esta base curricular comum, entendemos que um ponto positivo deve ser destacado: a adoção (assim como os PCN) da concepção interacionista de linguagem, em uma abordagem discursivo-enunciativa, com foco nas práticas sociais de leitura/escuta, escrita/produção textual, oralidade e análise linguística/semiótica. 
Considerando, conforme pontuam Bonini e Costa-Hübes (2019), que a BNCC é uma referência obrigatória, mas não é currículo; que seu papel é o de orientar a revisão e a elaboração dos currículos nos estados e municípios; que estabelece os objetivos que os estudantes devem atingir, mas que cabem aos currículos definir os caminhos para alcançar tais objetivos; despontou-se uma necessidade veemente de (re)formular os currículos municipais para adequá-los ao que foi estabelecido pela Base. Porém, essa adequação não resolve o desconforto dos professores, principalmente no que diz respeito à concepção de linguagem assumida no documento. É imprescindível investir na sua formação, na perspectiva de subsidiá-los teórica e metodologicamente para que se sintam aptos a trabalhar com a LP conforme a abordagem preconizada pelo documento parametrizador. Essa necessidade apontada pelos participantes foi que nos motivou a investir em uma PACC, com o intento de colaborativamente refletirmos sobre as concepções de linguagem que regem a prática pedagógica e analisar os resultados alcançados.

A pesquisa em formação de professores, sob a perspectiva da LA, justifica-se, segundo Miller (2013, p. 100) por quatro motivos: $1^{\circ}$ ) “o fortalecimento acadêmico para as práticas de formação de professores, já que ajuda a aprofundar os processos de formação, tanto inicial quanto continuada"; $2^{\circ}$ ) "no campo metodológico, a partir do momento em que as investigações na área têm desenvolvido inovações alinhadas com a pesquisa qualitativa e interpretativista nas ciências sociais"; $3^{\circ}$ ) "de ordem política dentro da academia, já que ela tem alavancado o status institucional dos formadores de professores, tanto no Brasil quanto no exterior"; $4^{\circ}$ ) pelas "questões de transformação social, de ética e de identidade dos diversos agentes envolvidos em processos de formação de professores".

Porém, ao delinear um percurso dessas pesquisas dentro da LA, a autora chama a atenção para a necessidade de fugir do caráter prescritivo, visando apenas o treinamento técnico de professores, para focalizá-los - participante e formadores - como "indivíduos reflexivos capazes de construir conhecimento através de processos interpretativos e reflexivos sobre suas próprias experiências" (MILLER, 2013, p. 108), o que pode ser realizado por meio da colaboração. 
Na verdade, nossa proposta era se distanciar do que Costa-Hübes (2013) denominam com uma política de formação continuada fragmentada, descontínua e utilitarista, "voltada especificamente a interesses educacionais ditados pelas políticas que surgem a cada mandato político no cenário nacional” (COSTA-HÜBES, 2013, p. 231). Embora se despontasse uma necessidade emergente ditada pela publicação da BNCC, pretendíamos garantir um processo formativo que contemplasse as necessidades vigentes da sala de aula.

Levando isso em conta, no primeiro semestre de 2019, em colaboração com as Secretarias de Educação de dois municípios do sudoeste do Paraná, planejamos, por meio de um projeto de extensão ${ }^{3}$, uma ação de formação continuada colaborativa, ofertando-a às coordenações pedagógicas, com o propósito de pensar a (re)construção do currículo de Língua Portuguesa, a partir do que propõe a BNCC. Em conjunto com as coordenações, vimos a necessidade de, em um segundo momento, estender a formação continuada também aos professores das escolas, focando agora no trabalho com a produção textual escrita e reescrita - nos anos iniciais do Ensino Fundamental, visto que, segundo as coordenações, este era o eixo de ensino no qual os professores mais apresentavam dificuldades e dúvidas sobre o encaminhamento. Compreendendo, assim como Nóvoa (1998), que todo processo de formação deve ter como referencial o saber docente, o reconhecimento e a valorização desse saber, concordamos em direcionar as reflexões para a temática solicitada.

Em parceria com as secretarias municipais dos dois munícipios, propusemos, no segundo semestre de 2019, o projeto de extensão "Produção textual e reescrita nos anos iniciais do ensino fundamental"4, visando, inicialmente, refletir sobre as concepções de linguagem que podem orientar/orientam o ensino de LP e como a concepção por nós adotada pode incidir no trabalho com a produção e reescrita textual.

\footnotetext{
${ }^{3}$ O projeto, intitulado "A BNCC: Pensando o currículo de Língua Portuguesa nos anos iniciais do Ensino Fundamental", está cadastrado na Pró-Reitoria de Extensão e Cultura da UFFS, sob registro EXT-2019-0041, com vigência entre abril e junho de 2019.

${ }^{4}$ Cadastrado na Pró-reitora de Extensão da Unioeste, sob número 58065/2019, com vigência entre agosto e novembro de 2019.
} 
A fim de garantir maior adesão dos professores, decidimos, conjuntamente, o melhor horário, a carga horária e o período de concretização dos estudos. Chegamos, assim, à decisão de que seriam trabalhadas seis oficinas/encontros, após o término das aulas do período vespertino, realizados ao longo do segundo semestre, totalizando 24 horas, distribuídas conforme o quadro 1. A distribuição dos encontros, em intervalos de duas a quatro semanas intencionou possibilitar que os professores articulassem as discussões desenvolvidas com as práticas em sala de aula.

Quadro 1 - Programação da formação continuada

\begin{tabular}{|l|l|c|}
\hline \multicolumn{1}{|c|}{ Data e horário } & \multicolumn{1}{|c|}{ Conteúdo } & \multicolumn{1}{c|}{$\begin{array}{c}\text { Carga } \\
\text { horária }\end{array}$} \\
\hline 26 de agosto de 2019 & Concepções de linguagem & 04 horas \\
\hline 09 de setembro de 2019 & Concepções de escrita & 04 horas \\
\hline 23 de setembro de 2019 & $\begin{array}{l}\text { A produção textual nos anos iniciais - comandos } \\
\text { de produção }\end{array}$ & 04 horas \\
\hline 21 de outubro de 2019 & $\begin{array}{l}\text { A produção textual nos anos iniciais - análise diag- } \\
\text { nóstica de textos }\end{array}$ & 04 horas \\
\hline 04 de novembro de 2019 & $\begin{array}{l}\text { A produção textual nos anos iniciais - correção e } \\
\text { reescrita pelo professor }\end{array}$ & 04 horas \\
\hline 18 de novembro de 2019 & $\begin{array}{l}\text { A produção textual nos anos iniciais - correção e } \\
\text { reescrita pelo aluno }\end{array}$ & 04 horas \\
\hline & \multicolumn{1}{|c|}{ Total } & 24 horas \\
\hline
\end{tabular}

Fonte: Elaborado pelas autoras

Nesses moldes, a formação atendeu a 74 professores. No entanto, houve uma variação de participantes a cada encontro. Deste total, apenas 31 professores (que equivale a $42 \%)$ participaram dos seis encontros, 14 (20\%) participaram de cinco encontros e $7(10 \%)$, de quatro encontros apenas. Os demais (22 professores, ou 28\%) contaram com uma participação igual ou inferior a 50\% do curso. Esse alto índice de desistência, somado às ausências dos participantes em alguns encontros pode ser decorrente da compreensão de alguns professores de que um curso de formação deve servir para assessorá-los em sua prática na sala de aula e que sua participação em "cursos" é para buscar "receitas" de como 
dar uma boa aula. Mas, quando compreenderam que se tratava de uma formação colaborativa, com a qual deveriam colaborar, no decorrer do processo, participando das leituras e atividades solicitadas, optaram por se afastar da formação.

Segundo Nóvoa (1997), faz-se necessário que o educador da atualidade se desvincule dos elos antigos que os caracterizavam como carentes de assistencialismo didático, assistidos por "receitas" repassadas durante as formações. É importante que passem a compreender que qualquer formação exige um investimento pessoal, interesses sobre os percursos e os projetos próprios. Assim, a formação deve estimular a construção de um professor crítico-reflexivo, que contribua para o desenvolvimento do pensamento autônomo e que facilite as dinâmicas de autoformação participada.

A formação continuada, portanto, foi proposta em formato de curso de extensão, na busca de atender à necessidade de certificação para os professores participantes, considerando que os encontros foram após o horário de trabalho, em uma tentativa de corresponder aos moldes canonizados por cursos e certificação. No entanto, salientamos que o curso não seguiu o formato tradicional, em oficinas fechadas em si mesmas, com a simples exposição de conceitos e abordagens teóricas por parte de um professor formador. A partir das vivências dos participantes e da discussão das abordagens teórico-metodológicas, buscamos encontrar, colaborativa e coletivamente, caminhos metodológicos alternativos para o trabalho com a produção textual em sala de aula, ao longo da formação.

Desse modo, ao delinear o projeto de pesquisa, baseamo-nos nos pressupostos da Pesquisa-ação-crítico-colaborativa (PACC) proposta por Pimenta (2005), a qual permite que os professores reflitam criticamente sobre sua prática. A função do pesquisador, na PACC, segundo a autora é a de participar e "cientificizar" um processo de mudança já em andamento. Assim, nossa pesquisa, ao partir de uma necessidade apontada pelas equipes pedagógicas e pelos professores, em decorrência das transformações desencadeadas pela publicação da BNCC, buscou promover transformações nas ações e práticas desenvolvidas pelos próprios professores, por meio de problematizações e do confronto entre suas vivências e formações anteriores, com as experiências de colegas e as abordagens teóricas e metodológicas já consolidadas. 
Pimenta (2005) elenca algumas características da PACC, as quais buscamos seguir:

a) confirma-se a importância da realização de pesquisas-ação-críticocolaborativas entre a universidade e as escolas como condição fundamental no processo de desenvolvimento profissional de professores $[\ldots]$;

b) nesse processo é requisito essencial partir das necessidades dos professores envolvidos e delas evoluir, consensualmente, para objetivos de pesquisa;

c) a pesquisa-ação crítico-colaborativa apresenta resultado de alterações das práticas ao longo do processo. Este, no entanto, requer tempo para se implantar e amadurecer;

d) na medida em que os professores se percebem capazes de analisar, refletir e alterar suas práticas, eles se fortalecem como pessoas e como profissionais [...];

e) os pesquisadores da universidade não podem (não lhes compete) alterar o sistema de ensino [...]. Cabe-lhes fortalecer a profissionalidade dos professores, por meio de explicitação, registro, reflexão compartilhada, proposição, realização, acompanhamento e análise de projetos participativos a partir das necessidades dos professores e da percepção destes pelos pesquisadores [...]. (PIMENTA, 2005, p. 523)

Desse modo, a partir da demanda dos professores participantes, o objetivo da formação continuada proposta foi aprofundar, teórica e metodologicamente, conhecimentos relativos às concepções de linguagem e sua relação com a prática de produção textual, com vistas a refletir sobre as possibilidades de encaminhamentos em sala de aula. Para que isso se tornasse possível, nos orientamos por Magalhães (2004) que, assim como Pimenta (2005) e Miller (2013), defende a necessidade de formar professores reflexivos e críticos. Segundo a autora, embora já muitos pesquisadores venham apontando a necessidade de mudança, esta nem sempre ocorreu, especialmente na rede oficial de ensino brasileira. Magalhães (2004) aponta uma série de possíveis motivos para isso, considerando necessárias discussões que "incluem questões de compreensão da escola como um espaço cultural, social e político e não apenas como um local de transmissão de conhecimentos neutros e desvinculados do contexto particular de ação e da sociedade mais ampla. Incluem, também, a compreensão da linguagem como um espaço para reflexão e negociação" (MAGALHÃES, 2004, p. 45-46). A partir da percepção da escola como um espaço cultural, social e político, 
com a qual concordamos, a pesquisadora defende o papel central da linguagem para a formação de professores críticos e reflexivos, num viés colaborativo. Segundo a autora:

Colaborar, em qualquer contexto (pesquisa, formação contínua, sala de aula), significa agir no sentido de possibilitar que os agentes participantes tornem seus processos mentais claros, expliquem, demonstrem, com o objetivo de criar, para os outros participantes, possibilidades de questionar, expandir, recolocar o que foi posto em negociação. (MAGALHÃES, 2004, p. 56)

Partindo daí, Magalhães (2004, p. 57-58) propõe quatro momentos para esse trabalho colaborativo: descrever, informar, confrontar e reconstruir. O momento da "descrição" das ações em sala de aula visa um distanciamento do professor em relação a sua prática, de modo a levá-lo a questionar as razões que o motivam a agir assim e o que isso significa para a aprendizagem do aluno. Ao provocar essa reflexão, o formador deve "criar espaço" para relacionar as práticas em sala de aula às perspectivas teóricas que as embasam. Desse momento, então, passamos à “informação” que, posteriormente ou concomitantemente, possibilita a "confrontação" "em que o agente se questiona: como cheguei a ser assim? Qual a função social desta aula, neste contexto particular de ação? Que tipo de aluno estou formando? Qual a função das escolhas feitas na construção da cidadania?” (MAGALHÃES, 2004, p. 58). É essa compreensão que pode, segundo a autora, levar o professor à "reconstrução" de suas práticas em sala de aula.

Para tornar efetivos esses quatro momentos, a autora sugere dois tipos de atividades que apresentam a linguagem como central: a produção de diários e a organização de sessões reflexivas. O diário seria produzido pelo professor em dois momentos: ao início do curso (visando descrever e visualizar a própria ação docente) e ao final do curso (buscando, além de descrever suas ações, também refletir criticamente e reconstruir essas ações). Embora consideremos o trabalho com o diário produtivo para a formação colaborativa, salientamos que o processo sugerido pela autora (em que os professores comparam os diários entre si e em que formadora e professores avaliem os diários em conjunto, por exemplo) funcione de modo mais efetivo em grupos menores de formação e/ou com carga horária ampliada. No trabalho que desenvolvemos, buscando atender às necessidades das redes municipais e 
dos professores participantes, a carga horária limitada e a quantidade de participantes, impossibilitaram essa organização. Por essa razão, adaptamos a proposta de Magalhães (2004) ao objetivo central de nossa pesquisa. E assim, em vez de diários, os professores participantes elaboraram, em grupo de até seis professores, cartazes nos quais apresentaram (no início e no final da formação) suas concepções de linguagem. Este procedimento nos permitiu, posteriormente, analisar se os estudos empreendidos geraram alguma mudança em suas compreensões.

As sessões reflexivas, por sua vez, visam a "a) formar profissionais críticos que reflitam sobre suas práticas e sobre a formação de seus alunos e b) contextualizar uma relação indivisível entre a teoria vista no curso e a prática da sala de aula, uma vez que o professor, na relação com o colega, vivencia os papéis de avaliador das práticas didáticas do colega e o de avaliado pelo colega" (MAGALHÃES, 2004, p. 60). Estas sessões ocorreriam, segundo a autora, a partir da análise de aulas (anônimas e dos próprios participantes), realizada por pequenos grupos, sendo registradas e analisadas, posteriormente pelo grupo maior, em conjunto com o formador. Novamente, propusemos uma adaptação a essa orientação da autora, considerando o tempo e o número de professores participantes, o que tornaria menos eficiente este processo. Dessa forma, a cada encontro, propusemos que, em grupos, os participantes discutissem e escrevessem sobre suas práticas na sala de aula para socializar, no encontro seguinte, com os colegas. Com esse encaminhamento, pudemos acompanhar, por meio da descrição das atividades, como estas eram realizadas previamente ao curso e, a partir das reflexões tecidas em cada encontro (momento de informar), foi possível verificar o confronto e a reconstrução de seus conhecimentos, isto é, como os encaminhamentos realizados em sala de aula iam sendo modificados a partir da discussão realizada na formação.

Com base nessa orientação metodológica, a cada encontro, o papel de pesquisadora colaboradora era principalmente o de informar após a descrição realizada no grupo, que motivava as questões a serem discutidas. Depois disso, passava a mediar também o confronto entre o que já faziam em sala de aula e as novas possibilidades de encaminhamentos didáticos. Os participantes iam entendendo, gradativamente, como diz Freire (1996, p. 20), 
a finitude do ser humano; que somos seres em processo de construção; que estamos sempre aprendendo; que devemos estar abertos à aprendizagem.

Delineado o encaminhamento da formação continuada colaborativa que buscamos seguir, partimos, na próxima seção, para a apresentação desse trabalho desenvolvido, de modo a analisar as possíveis mudanças em relação às concepções de linguagem dos professores participantes.

\section{A proposta de formação continuada colaborativa em ação}

Quando Geraldi, em 1984, nos questiona "Para que ensinamos o que ensinamos" e "Para que as crianças aprendem o que aprendem" (GERALDI, 2011[1984], p. 42), já nos chamava a atenção para o fato de que a forma como encaminhamos o trabalho com a linguagem em sala de aula são definidos pela resposta a estas questões. Assim, nossa postura metodológica será diferente se acreditamos que ensinamos o que ensinamos para que os alunos aprendam a ler, escrever e a falar bem e "corretamente" ou para que compreendam os diferentes usos da linguagem e ampliem seu repertório linguístico-discursivo, de modo a se inserirem e participarem ativa e criticamente nos diferentes contextos sociais. Nossos objetivos para o ensino de LP estão, portanto, intimamente ligados à nossa concepção de linguagem.

A partir dessa constatação, Geraldi (2011[1984]) nos apresenta três concepções de linguagem nas quais podemos nos ancorar para o ensino de LP: a linguagem como expressão do pensamento, a linguagem como forma de comunicação e a linguagem como forma de interação. Essas concepções relacionam-se, respectivamente, às duas tendências linguísticas problematizadas por Volóchinov (2018[1929]) - o subjetivismo idealista e o objetivismo abstrato - e com a proposta do Círculo de Bakhtin para superar essas duas tendências, assumindo-se, assim, a concep̧̧ão interacionista de linguagem, a qual é considerada a mais adequada nas propostas atuais para o ensino de Língua Portuguesa.

A realidade efetiva da linguagem não é o sistema abstrato de formas linguísticas nem o enunciado monológico isolado, também pouco o ato psicofisiológico de sua realização, mas o acontecimento social 
da interação discursivsa que ocorrer por meio de um ou de vários enunciados. (VOLOCHINOV, 2018[1929], p. 218-219)

No entanto, filiar-se à esta terceira concepção de linguagem pode ser uma atitude desafiadora para muitos docentes de LP, dado o fato de que, em grande parte dos casos, sua educação básica, e até sua formação inicial - seja em Letras ou em Pedagogia -, esteve alinhada à concepção de linguagem como "expressão do pensamento" ou como "instrumento de comunicação". Essa base da formação básica é tão forte que, ainda que já tenham entrado em contato com as discussões referentes às diferentes concepções de linguagem e seus reflexos no ensino de linguagem, pode ser difícil a eles filiarem-se à concepção de linguagem como "forma de interação" de modo consistente, exatamente porque lhe faltam subsídios teóricos que lhes façam compreender a representatividade dessa adoção em seus encaminhamentos didático-pedagógicos. Por essa razão, consideramos primordial, no processo formativo, amadurecer a compreensão dessas concepções, estabelecendo relações com os encaminhamentos metodológicos em sala de aula.

Tendo isso em vista, para o primeiro encontro da formação, após apresentar a proposta de trabalho como uma ação colaborativa e destacar que as concepções de linguagem que carregamos atuam na forma como encaminhamos o seu ensino e, portanto, da produção textual, solicitamos aos participantes que, em grupos de até seis pessoas, anotassem, em cartazes, como concebiam a linguagem. Posteriormente, pedimos que socializassem essa compreensão com os demais colegas participantes, atividade que compreendemos dentro da PACC, como o momento de "descrever", proposto por Magalhães (2004). Como resultado, foram produzidos dez cartazes, dos quais apresentamos três que consideramos representativos dos demais: 
Figura 1 - Concepções de linguagem - cartazes iniciais

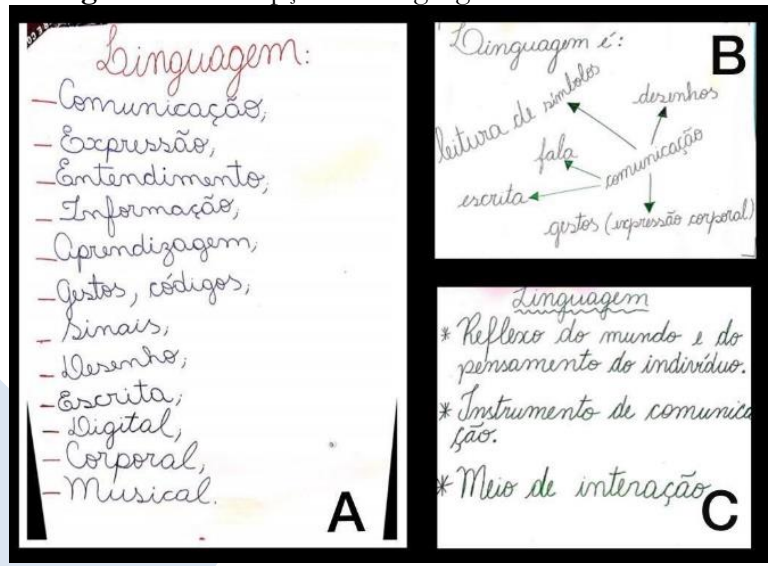

Fonte: Banco de dados da pesquisadora.

Nos dois primeiros cartazes (Figuras 1A e 1B), podemos verificar, essencialmente, a presença das concepções de linguagem como "expressão do pensamento" e como "instrumento de comunicação” (GERALDI, 2011[1984]), por meio da presença das palavras "expressão" e "comunicação".

A concepção da linguagem como expressão do pensamento, conforme Geraldi (2011[1984], p. 41), “ilumina, basicamente, os estudos tradicionais. Se concebemos a linguagem como tal, somos levados a afirmações - correntes - de que pessoas que não conseguem se expressar não pensam”. Essa concepção remete à primeira tendência exposta por Volóchinov (2018 [1929]): o subjetivismo idealista. Ao conversar com os participantes, informamos que se partimos dessa concepção de linguagem para o trabalho com a produção textual - foco da formação continuada -, nos orientaremos para propostas de produção de texto totalmente descontextualizadas, centradas em um tema (Ex. Escreva sobre o mar), acreditando que o aluno criará o seu texto a partir de seu dom/inspiração (MENEGASSI, 2010). Escrever, a partir dessa concepção, é a verdadeira expressão dos pensamentos, exteriorizados criativamente. A escrita, nesse caso, está desvinculada dos contextos re- 
ais de uso da linguagem. Como resultado, a produção textual teria como objetivo, primeiramente, verificar se o aluno tem condições de exteriorizar o pensamento de forma lógica para, posteriormente, conferir se domina as regras gramaticais e ortográficas.

Essa concepção esteve presente em quatro dos dez cartazes produzidos inicialmente. Entretanto, é importante ressaltar que, em todos, está articulada também com ao menos uma das outras concepções de linguagem. Na Figura 1A, por exemplo, verificamos também a concepção de linguagem como "instrumento de comunicação". Nesse cartaz, percebemos, além da palavra-chave "comunicação", a utilização das palavras "entendimento" e "informação", as quais entendemos estar vinculadas também à segunda concepção de linguagem.

Essa concepção, segundo Geraldi (2011[1984], p. 41) “está ligada à teoria da comunicação e vê a língua como código (conjunto de signos que se combinam segundo regras) capaz de transmitir ao receptor certa mensagem. Em livros didáticos, é a concepção confessada nas instruções ao professor, nas introduções, nos títulos, embora em geral seja abandonada nos exercícios gramaticais". A teoria da comunicação, mencionada por Geraldi, corresponde à teoria de Jakobson (2008[1976]), discípulo de Saussure que, amparando-se no paradigma estruturalista, defende a linguagem como um instrumento de comunicação organizado por elementos que, cada um a seu modo, tem uma função no processo comunicativo, quais sejam: emissor, receptor, referente, mensagem, código e canal. Esta teoria foi muito difundida na década de 1970, influenciando o ensino de LP de tal modo que esta disciplina chegou a ser denominada, conforme relata Soares (2002), como "Comunicação e Expressão".

Volóchinov (2018[1929] tece uma crítica às bases teóricas dessa tendência, a qual o autor vincula com os estudos linguísticos formalistas, que marcaram o surgimento da teoria linguística enquanto ciência. $\mathrm{O}$ autor denomina-a de objetivismo abstrato, pelo fato de, nos estudos formais, compreenderem que o centro organizador de todos os fatos da língua é o sistema linguístico, composto de formas fonéticas, gramaticais e lexicais. Nesta orientação, os elementos estáveis seriam recebidos da comunidade linguística, como algo já posto, um conjunto de formas dadas, que não pudessem ser alteradas. 
Compreender a linguagem desse modo consiste em considerar que tem a função de transmitir uma mensagem a um receptor passivo que apenas deve compreender/decodificar esta mensagem. A partir desse entendimento, então, o ensino de LP passa a focar na descrição linguística e na decodificação de fragmentos de textos.

É importante ressaltarmos que essa concepção de linguagem esteve presente nos dez cartazes produzidos no momento inicial da formação. Em cinco deles, apresenta-se nos mesmos moldes verificados na Figura 1B: a comunicação como centro da linguagem e, vinculadas a ela, as diferentes modalidades de linguagem (escrita, fala, expressão corporal, pintura, musical, entre outras). Durante a socialização, pudemos perceber que, de um modo geral, a Teoria da Comunicação esteve presente de forma bastante marcante na formação inicial dos professores, os quais vinculavam a comunicação às funções da linguagem propostas pelo linguista (JAKOBSON, 2008[1976]).

Em alguns cartazes produzidos, verificamos que há um extravasamento dessas duas tendências, em direção ao que o Círculo de Bakhtin propõe como "síntese dialética" (VOLÓCHINOV, 2018[1929], p. 199-200), ao defender uma nova compreensão: da linguagem como forma de interação discursiva. Segundo Geraldi (2011 [1984], p. 41), nessa terceira concepção, "mais do que possibilitar uma transmissão de informações de um emissor a um receptor, a linguagem é vista como um lugar de interação humana. Por meio dela, o sujeito que fala pratica ações que não conseguiria levar a cabo, a não ser falando; com ela o falante age sobre o ouvinte, constituindo compromissos e vínculos que não preexistiam à fala".

É o que podemos perceber no cartaz da Figura 1C, que traz um resumo das três concepções de linguagem, conforme apresentadas por Geraldi. Essa configuração pode estar relacionada ao fato de que participaram desse grupo duas coordenadoras pedagógicas que estiveram presentes no projeto de extensão ofertado no primeiro semestre de 2019. Essa constatação sugere, então, que já houve uma ampliação nas formas de conceber a linguagem dos participantes do projeto anterior. Além desse cartaz, verificamos, em um segundo, a utilização das palavras "agir" e "relacionar-se"; e, em um terceiro, o uso de "socialização", junto a outras que remetem à linguagem como "expressão de pensamento" e 
como "instrumento de comunicação", o que compreendemos como um avanço em direção à compreensão da linguagem como "interação social".

Após a produção e a socialização dos cartazes, passamos ao momento de informar, ancorado nas considerações de Volóchinov (2018[1929]) e de Geraldi (2011[1984]), articulando-as aos encaminhamentos metodológicos para cada uma das concepções expostas pelo último autor, conforme as discussões apresentadas na análise. Chamamos a atenção para o fato de que compreender como cada uma dessas concepções atua no ensino de LP parece não ser tarefa simples. Concordamos com Rosa (2014, p 18), ao refletir sobre as formas como o trabalho com LP é encaminhado, nesse caso, especificamente, com a produção e a reescrita de textos:

Apesar de tanta publicação refletindo sobre como deveria ser conduzido o processo de produção e reescrita de textos em sala de aula, apesar de tantos pesquisadores refletirem sobre o aspecto dialógico da linguagem, ainda, na sala de aula, muitas vezes, persistem atividades mecânicas de escrita, em que não se produzem textos, mas realizam-se exercícios de escrita. Isso, muitas vezes decorre da incompreensão das propostas teórico-metodológicas postas nos documentos pedagógicos, justificando pesquisas nesse aspecto. (ROSA, 2014, p. 18)

Justamente por isso, optamos por propor uma ação colaborativa voltada aos professores, a partir de uma necessidade por eles expostas, buscando articular as propostas teórico-metodológicas para a produção e reescrita de textos apresentadas na BNCC com as práticas desenvolvidas por eles em sala de aula. Para que isso se tornasse possível, mostrou-se imprescindível amadurecer a discussão sobre as concepções de linguagem que ancoram essas práticas. Por essas razões, a cada encontro, reforçamos a discussão sobre tais concepções, enquanto abordávamos também as questões teórico-metodológicas para a produção e reescrita de textos em sala de aula.

Assim, no segundo encontro, após “descrever” as atividades de escrita e produção textual desenvolvidas pelos participantes em sala de aula, introduzimos as concepções de escrita apresentadas por Menegassi (2010), buscando articulá-las às concepções de lingua- 
gem: a escrita com foco na língua, como dom/inspiração, como consequência e como trabalho. A partir dessa "informação", foi possível aos professores "confrontar" a forma como trabalhavam a escrita e a produção textual em sala de aula com as concepções de escrita e linguagem apresentadas e, assim, refletir sobre as mudanças necessárias para que seus objetivos, ao trabalhar com Língua Portuguesa, fossem efetivamente alcançados e, assim, tornasse possível o caminho para a "reconstrução" de conhecimentos e de práticas pedagógicas.

No terceiro encontro, o foco foi direcionado aos encaminhamentos e comandos de produção textual. Da mesma forma, os professores, em grupos, descreveram e socializaram os modos como costumavam encaminhar as produções em sala de aula. $\mathrm{O}$ momento de “informar” deu-se a partir das orientações de Geraldi (2013[1991]), Costa-Hübes (2012a) e Costa-Hübes (2016). Recorremos, também, às orientações da BNCC (BRASIL, 2017) e do Referencial Curricular do Paraná (PARANÁ, 2018) para dialogar com as propostas desses autores. Por meio desse "confronto", os professores chegaram à conclusão de que não partiam desses pressupostos teóricos e afirmaram que poderia ser uma possibilidade viável para alcançar os objetivos de ensino. A partir disso, em grupos, reuniram-se para pensar possibilidades de produção textual amparadas em tais orientações teórico-metodológicas. Em concordância, no decorrer do mês em que não haveriam encontros ${ }^{5}$, seriam desenvolvidos trabalhos de produção textual a partir dos pressupostos discutidos até esse momento. Ainda, combinamos, em grupo, que os textos, em sua primeira versão, não seriam corrigidos antes do encontro seguinte, quando começaríamos a discutir as possibilidades para a análise, diagnóstico e correção de textos.

Após esse intervalo, em que os professores planejaram e desenvolveram as atividades de produção textual em sala de aula, houve mais um momento de socialização da "reconstrução" de suas ações e práticas em sala de aula, possibilitada por meio das discussões

\footnotetext{
${ }^{5} \mathrm{O}$ cronograma do curso foi elaborado de modo a possibilitar que os professores participantes buscassem ressignificar o trabalho desenvolvido em sala de aula, considerando as discussões realizadas na formação. Então, de modo a enriquecer a experiência, no decorrer do mês sem encontros, buscaram desenvolver atividades articuladas com a concepção de linguagem como forma de interação.
} 
colaborativas realizadas na formação continuada. Os professores avaliaram as potencialidades e as dificuldades da abordagem e, em sua maioria, embora ainda tivessem dúvidas sobre o processo, avaliaram a mudança positivamente, visto que, à primeira vista, obtiveram textos que atenderam às propostas encaminhadas e maior engajamento dos alunos na atividade. Posteriormente, tivemos mais um momento de "descrever" o modo como eram encaminhadas as correções dos textos dos alunos.

A partir daí, no quarto, no quinto e no sexto encontro, focamos na análise e diagnóstico dos textos dos alunos (COSTA-HÜBES, 2012b), visando pensar como a produção textual pode direcionar também as atividades de análise linguística, e nas possibilidades de correção e rescrita dos textos pelo professor e pelo aluno, a partir das considerações de Ruiz (2010) e da classificação das correções, proposta pela autora, como indicativa, resolutiva, classificatória e textual interativa. A partir dessa discussão, os professores refletiram sobre suas próprias práticas, situando-as nessa classificação, e avaliaram as mudanças necessárias para tornar também o momento da correção mais adequado ao modo de conceber e encaminhar o trabalho com a linguagem e a produção de texto.

Por fim, com o intuito de verificarmos se a formação continuada, desenvolvida nesses moldes, gerou alguma mudança nas compreensões dos professores participantes, solicitamos que, novamente, em grupos de até seis pessoas, produzissem novos cartazes com suas concepções de linguagem. Com a desistência de quase 30\% dos participantes, obtivemos, neste momento, sete cartazes, dos quais selecionamos quatro representativos, na Figura 2.

Ao analisar os cartazes produzidos no último encontro, podemos concluir que, ainda que não totalmente, houve uma alteração considerável no modo como os participantes concebem a linguagem. Dos sete cartazes, seis empregaram a palavra "interação" ou, no caso do cartaz, na Figura 2C, "a linguagem é ação entre os sujeitos". É interessante perceber a reconstrução presente, em quase todos os cartazes, em que seus produtores buscaram organizar suas compreensões, sem prender-se às cópias dos textos lidos e discutidos durante os encontros. Em um único cartaz (Figura 2A), apresenta-se as três concepções de linguagem, o que nos parece que, neste caso, seria preciso um tempo maior de 
estudos e reflexões para que esses participantes pudessem assumir uma dessas concepções de linguagem.

Figura 2 - Concepções de linguagem - cartazes finais

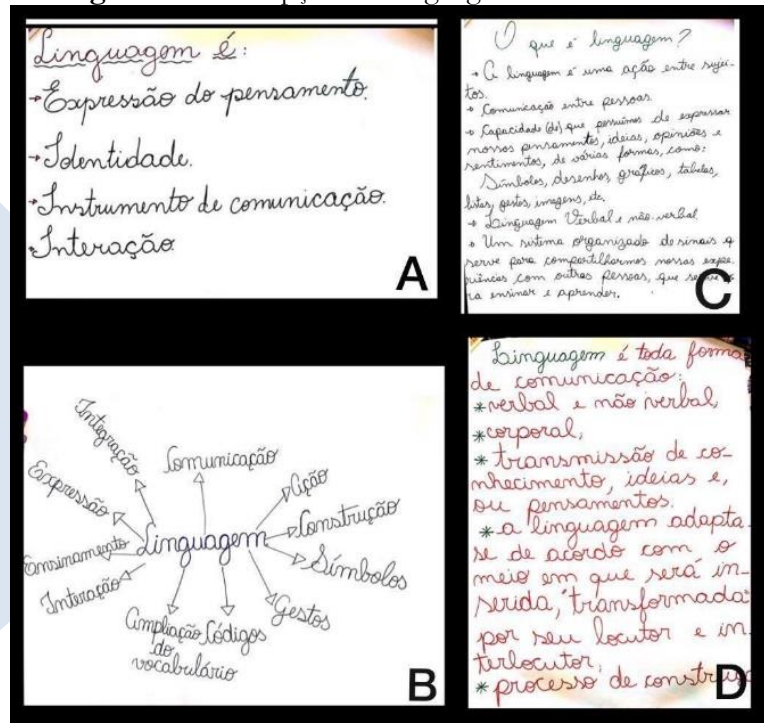

Fonte: Banco de dados da pesquisadora.

Nos demais cartazes, percebemos que a palavra "comunicação" deixou de ocupar o lugar central, sendo substituída por "linguagem" (a exemplo da Figura 2B) em três cartazes. Quando os participantes optaram por organizar o cartaz em tópicos, verificamos que, embora a "comunicação" ainda apareça entre as palavras elencadas, não é mais o conceito definidor da linguagem, como podemos perceber na Figura 2C e em um segundo cartaz, não apresentado aqui. Apenas um deles (Figura 2D) ainda traz a comunicação em primeiro plano e apresenta a ideia de "transmissão", alinhada à linguagem como expressão do pensamento. Entretanto, ainda assim, os dois últimos tópicos chamam a atenção: "a linguagem adapta-se de acordo com o meio em que será inserida, 'transformada' por seu locutor e interlocutor" e "processo de construção". Inferimos, então, que os autores do cartaz ampliaram a concepção de linguagem cristalizada em regras gramaticais e ortográficas, em que 
falantes e ouvintes são passivos, para percebê-la em processo, em movimento, na "interação" ativa entre os sujeitos que a transformam de acordo com o contexto de uso, ainda que não utilize essa palavra-chave.

Com essa análise, consideramos que, embora parcialmente, o caminho da colaboração, conforme defendem Magalhães (2004), Pimenta (2005) e Miller (2013), é uma possibilidade válida para a formação continuada, desde que sejam respeitados os processos de construção de conhecimento dos participantes, sem objetivar, portanto, impor ou forçar essas mudanças. Logo, é importante ressaltar a importância da oferta de formação de modo contínuo, possibilitando, cada vez mais, o amadurecimento desses conhecimentos.

\section{Considerações finais}

A formação continuada, seguindo as orientações da PACC, mostraram-se, conforme verificamos nas pesquisas já desenvolvidas por outros autores, eficiente na reflexão e aprofundamento da base epistemológica, teórica e metodológica para o ensino de LP. A partir da análise dos cartazes produzidos ao início e ao final da formação, pudemos constatar que houve, sim, uma mudança no modo como os participantes concebem a linguagem. A partir das discussões desenvolvidas durante o processo, reconhecemos que houve um movimento de mudança em direção ao trabalho com produção textual que considera a linguagem como interação entre sujeitos. Nas produções encaminhadas pelos professores em sala de aula, descritas durante o processo, os professores ressaltaram o interesse dos alunos na produção de texto porque agora eles tinham uma razão para escrever, escreviam para interlocutores reais, inseridos em uma situação de interação. Relataram que, a partir das reflexões propiciadas pela formação colaborativa, solicitaram a seus alunos que produzissem convites, cardápios e lista de compras para a organização de festas entre turmas, a produção de uma biografia para presentear os avós e a organização de resenhas literárias para motivar colegas para a leitura.

Entretanto, é importante ressaltar que nem todos nossos questionamentos foram respondidos. Considerando a relação entre professores da educação básica e professora formadora, vinculada à Universidade, "acostumada" a um contexto tradicional de ensino, 
questionamos como seria possível verificar quanto os professores participantes foram realmente inseridos na produção de conhecimentos. Além disso, em decorrência da adaptação da proposta de Magalhães (2004), nos questionamos: a necessidade de trabalhar com grupos maiores e, tempos mais curtos, impossibilitaria uma reflexão mais aprofundada, conforme propõe a autora? Será possível realmente qualificar essas contribuições?

Pensando nos termos dessa modernidade recente que cobra mudanças cada vez mais rápidas (MOITA LOPES, 2013), a pesquisa em LA que busca envolver os professores da Educação Básica, inseridos nas complexas condições de trabalho, nem sempre é possível. Mas, ainda assim, acreditamos que é válido continuar a investir no processo de formação de professores, nesse viés colaborativo, em pesquisas futuras, propondo parcerias de pesquisa entre instituições de ensino. Desse modo, acreditamos que, mesmo com as adaptações à proposta de Magalhães (2004), buscamos alcançar o objetivo proposto pela autora: "a construção de identidades em que os professores se vejam como agentes críticos e nunca neutros, agentes que tomam decisões que levem em conta as questões socioculturais e os interesses que embasam as ações escolhidas e, que, semelhantemente, formem alunos reflexivos e críticos" (MAGALHÃES, 2004, p. 62).

\title{
COLLABORATIVE CONTINUING EDUCATION: A RESEARCH EXPERIENCE
}

\begin{abstract}
The aim of this paper is to present the partial results of a collaborative-critical-actionresearch (Pimenta, 2005), developed within the scope of continuing education for teachers in the early years of elementary school, in order to investigate if the collaborative actions proposed would cause changes in the language conceptions of the participating teachers. In line with the concerns of Applied Linguistics, we developed a qualitative interpretative research (Bortoni-Ricardo, 2008), following the assumptions of collaborative-critical-action-research, in an adaptation of the proposal of Magalhães (2004). Based on the understanding that language conceptions affect the methodological directions of working with language (Geraldi, 2011 [1984]), the training took place in the second semester of 2019, and initially had the participation of 74 teachers, in six meetings distributed throughout the semester, totaling 24 hours. From the analysis of posters produced at the beginning and at the end of the training, we verified that there was a significant change in the concepts presented by the participants.
\end{abstract}

KEYWORDS: Collaborative actions; Collaborative critical action research; Teacher education. 


\section{REFERÊNCIAS}

VOLÓCHINOV, V. (Círculo de Bakhtin). Marxismo e filosofia da linguagem: problemas fundamentais do método sociológico na ciência da linguagem. 2. ed. São Paulo: Editora 34, 2018[1929].

BOHN, H. I. Ensino e aprendizagem de línguas: os atores da sala de aula e a necessidade de rupturas. In: MOITA LOPES, L. P. da. (org.). Linguística aplicada na modernidade recente: festschrift para Antonieta Celani. São Paulo: Parábola Editorial, 2013, p. 79-98.

BONINI, Adair.; COSTA-HÜBES, Terezinha da Conceição. O contexto de produção da Base Nacional Comum Curricular (BNCC): cenas dos bastidores. In: COSTA-HÜBES, T. da C.; KRAEMER, M. A. D. (Orgs.). Uma leitura crítica da Base Nacional Comum Curricular: compreensões subjacentes. Campinas, Mercado de Letras, 2019. p. 17-39.

BORTONI-RICARDO, S. M. O professor pesquisador: introdução à pesquisa qualitativa. São Paulo, Parábola Editorial, 2008.

BRASIL. Base Nacional Comum Curricular. Brasília: MEC/SEB, 2017.

BRASIL. Parâmetros curriculares nacionais: Língua Portuguesa. Brasília: Secretaria de Educação Fundamental, 1997.

CAVALVANTI, M. C. Educação linguística na formação de professores de línguas: intercompreensão e práticas translíngues. In: MOITA LOPES, L. P. da. (org.). Linguística aplicada na modernidade recente: festschrift para Antonieta Celani. São Paulo: Parábola Editorial, 2013, p. 211-226.

COSTA-HÜBES, Terezinha da Conceição. 2012a. Reflexões sobre os encaminhamentos de produção textual: enunciados em diálogo com outros enunciados. In: Encontro do CELSUL - Círculo de Estudos Linguísticos do Sul, 10, 2012a, Cascavel. Anais do X Encontro do CELSUL. Cascavel: UNIOESTE, 2012a, p. 1-15.

- Análise de textos de alunos dos anos iniciais: orientações para um possível diagnóstico. Working Papers em Linguística, v. 13. n. 3, p. 01-20, 2012b.

FREIRE, P. Pedagogia da autonomia: saberes necessários à prática educativa. 25. ed. São Paulo: Paz e Terra, 1996.

GEDOZ, S. A formação continuada e suas implicações no trabalho com os gêneros discursivos: um estudo de caso com docentes dos anos iniciais. 2011. 189 f. Dissertação (Mestrado em Letras) - Universidade Estadual do Oeste do Paraná, Cascavel, 2011.

GERALDI, J. W. Portos de Passagem. 5. ed. São Paulo: Martins Fontes, 2013[1991]. . O texto na sala de aula. 5. ed. São Paulo: Ática, 2011[1984].

GUEDES, P. C. Formação do professor de português: que língua vamos ensinar?. São Paulo: Parábola Editorial, 2006. 
JAKOBSON, R. Linguística e Comunicaşão. 25. ed. São Paulo: Cultrix, 2008[1976].

KLEIMAN, A. B. Agenda de pesquisa e ação em Linguística Aplicada: problematizações. In: MOITA LOPES, L. P. da. (org.). Linguística aplicada na modernidade recente: festschrift para Antonieta Celani. São Paulo: Parábola Editorial, 2013, p. 39-58.

LEFFA, V. J. A auto-heteroecoformação tecnológica. In: MOITA LOPES, L. P. da. (org.). Linguística aplicada na modernidade recente: festschrift para Antonieta Celani. São Paulo: Parábola Editorial, 2013, p. 59-78.

MAGALHÃES, M. C. C. A linguagem na formação de professores reflexivos e críticos. In: MAGALHÃES, M. C. C. (org.). A formação do professor como profissional crítico: linguagem e reflexão. Campinas: Mercado das Letras, 2004, p. 45-62.

MENEGASSI, R. J. Concepções de escrita. In: SANTOS, A. R. dos; RITTER, L. C. B.; MENEGASSI, R. J. (orgs.). Escrita e ensino. 2. ed. Maringá: EDUEM, 2010, p. 11-24.

MILLER, I. K. de. Formação de professores de línguas: da eficiência a reflexão crítica e ética. In: MOITA LOPES, L. P. da. (org.). Linguística aplicada na modernidade recente: festschrift para Antonieta Celani. São Paulo: Parábola Editorial, 2013, p. 99-122.

MOITA LOPES, L. P. da. Linguística aplicada na modernidade recente: festschrift para Antonieta Celani. São Paulo: Parábola Editorial, 2013.

NÓVOA, A. Dize-me como ensinas, dir-te-ei quem és e vice-versa. In: Fazenda, I. (org.). A pesquisa em educaşão e as transformacões do conhecimento. 2. ed., Campinas: Papirus, 1997, p.29-41.

Profissão professor. Porto, Portugal: Porto Editora, 1998.

PARANÁ. Referencial Curricular do Paraná: princípios, direitos e orientações. Curitiba: SEED, 2018.

PIMENTA, S. G. Pesquisa-ação crítico-colaborativa: construindo seu significado a partir de experiências com a formação docente. Educação e Pesquisa. v. 3 n. 31, p. 521-539, 2005.

ROSA, D. C. da. Encaminhamentos de produção de textos nos anos iniciais: um exercício de escrita ou uma atividade de interação? 2014. 245 f. Dissertação (Mestrado em Letras) Universidade Estadual do Oeste do Paraná, Cascavel, 2014.

ROSSI, J. C. Ações colaborativas nos anos iniciais: um olhar para as práticas de formação e reescrita textual em formação continuada. 2019. 176 f. Dissertação (Mestrado em Letras) Universidade Estadual do Oeste do Paraná, Cascavel, 2019.

RUIZ, E. M. S. D. Como corrigir redações na escola.. Campinas: Mercado das Letras, 2001.

SOARES, M. Português na escola: história de uma disciplina curricular. In: BAGNO, M. (ed.). Linguística da norma. São Paulo: Edições Loyola, 2002, p. 155-177. 
TURKIEWICZ, R. de O. S. Ações colaborativas para encaminhamentos da produção e da reescrita textual no ensino fundamental. 2016. 370 f. Dissertação (Mestrado em Letras) - Universidade Estadual do Oeste do Paraná, Cascavel, 2016.

Recebido em: 23/04/2020.

Aprovado em: 22/05/2020. 